
\title{
25 Research Soure \\ Effects of Snow Manipulation on Larch Trees in the Taiga Forest Ecosystem in Northeastern Siberia
}

\section{Ruslan Shakhmatov}

Hokkaido University Graduate School of Environmental Science: Hokkaido Daigaku Daigakuin Kankyo Kagakuin Chikyu Kankyo Kagaku Kenkyuin

\section{Shuhei Hashiguchi}

Hokkaido University Graduate School of Environmental Science: Hokkaido Daigaku Daigakuin Kankyo Kagakuin Chikyu Kankyo Kagaku Kenkyuin

\section{Trofim C. Maximov}

Institute for Biological Problems of Cryolithozone SB RAS: Institut biologiceskih problem kriolitozony SO RAN

Atsuko Sugimoto ( $\sim$ atsukos@ees.hokudai.ac.jp )

Hokkaido University https://orcid.org/0000-0002-2003-7148

\section{Research article}

Keywords: Boreal forest, Taiga, Larch, Snow manipulation, Permafrost, Stable isotopes, Phenology, Nutrient, Soil Moisture

Posted Date: August 4th, 2021

DOI: https://doi.org/10.21203/rs.3.rs-753116/v1

License: () (i) This work is licensed under a Creative Commons Attribution 4.0 International License. Read Full License

Version of Record: A version of this preprint was published at Progress in Earth and Planetary Science on January 11th, 2022. See the published version at https://doi.org/10.1186/s40645-021-00460-5. 


\section{Abstract}

Changes in winter precipitation (snow) may greatly affect vegetation by altering hydrological and biochemical processes. To understand the effects of changing snow cover depth and melt timing on the taiga forest ecosystem, a snow manipulation experiment was conducted in December 2015 at the Spasskaya Pad experimental larch forest in Eastern Siberia, which is characterized by a continental dry climate with extreme cold winters and hot summers. Variables including soil temperature and moisture, oxygen and hydrogen isotope ratios of soil moisture and stem water, foliar nitrogen and carbon contents and their isotopes, phenology, and soil inorganic nitrogen were observed at snow removal (SNOW-), snow addition (SNOW+), and CONTROL plots. After snow manipulation, the soil temperature at the SNOW- plot decreased significantly compared to the CONTROL and SNOW+ plots. At SNOW-, snowmelt was earlier and soil temperature was higher than at other plots during spring because of low soil moisture caused by less snowmelt water. Despite the earlier snowmelt and higher soil temperature in the SNOW- plot in the early growing season, needle opening and shoot elongation were delayed. Leaf chemistry also differed between the CONTROL and SNOW+ plots. The needle nitrogen content in the SNOW- plot was lower in the middle of July, whereas no difference was observed among the three plots in August. The soil inorganic nitrogen content of each plot corresponded to these results. The amount of soil ammonium was lower in the SNOW- plot than in the other plots at the end of July, however, once production started at the end of August, the amount of soil ammonium in the three plots was comparable. Extremely low soil temperatures in winter and freeze-thaw cycles in spring at the SNOW- plot may have affected these results.

\section{Introduction}

Snow plays an important role in the ecosystems of the Northern Hemisphere (Chapin et al., 2000; Vavrus, 2007). Snow cover acts as an insulator in winter and regulates the water and nutrient balance, thereby influencing material cycling in summer (Aerts et al., 2004; Kreyling et al., 2012; Freppaz et al., 2018). As stated in the IPCC Fifth Assessment Report, the snow-covered area is declining as the southern boundary turns into a snow-free area (Vaughan et al., 2013). Because of global warming, snow-covered areas are expected to decrease and precipitation events are expected to become less frequent and intense (Huntington, 2006; Deser et al., 2010; Callaghan et al., 2011).

Although a general decrease in the depth of snow cover is expected, snow depth may increase in cold permafrost regions. According to simulation models by Park et al. (2014), snow depth is expected to increase in Siberia by $0.99 \mathrm{~mm}$ per year. This modeled trend is in accordance with observations from the central and western Siberia regions of Russia (Bulygina et al., 2009; Bulygina et al., 2011). Snow cover depth and duration have a major effect on ecosystems through their influence on the soil water balance and thermal regimes, nutrient availability, and duration of the growing season (Schimel et al., 2004; Grippa et al., 2005; Loranty et al., 2018). Additionally, changes in snow depth and density have a significant influence on the soil temperature (Zhang, 2005; Callaghan et al., 2011). In continuous permafrost regions, deeper snow cover can lead to a significant increase in mean annual ground 
temperatures, a reduction in the winter freezing depth, and an increase in soil moisture in spring and summer (Morse et al., 2012; Johansson et al., 2013; Park et al., 2015; Karjalainen et al., 2019). Such phenomena were observed in Eastern Siberia in 2004-2007 with heavy summer rainfall and winter snowfall (lijima et al., 2010). Interannual variations in snow cover conditions (timing, duration, density, and thickness) also have a strong influence on long-term ground temperatures in cold regions (Aerts et al., 2004). During winter and early spring, arctic soil temperatures mainly depend on the properties of snow cover and regional climate, and even small changes in snow cover can have a strong impact on soil frost frequency and intensity (Walker et al., 1999). In addition to the soil temperature, an increase in snow cover may cause soil subsidence and waterlogging in permafrost regions with a high ice content (Nauta et al., 2015). In high-latitude ecosystems, snowmelt timing controls not only hydrometeorological processes, but also many biological processes such as plant phenology and productivity. There are many case studies of snow manipulation experiments with changing a depth of snow cover (e.g., Wipf and Rixen, 2010).

Snow cover affects soil moisture in the early growing season because approximately half of the snow water equivalent (SWE) infiltrates into the soil after snow melt (Sugimoto et al., 2003). Increased water availability, especially during the early growing season, can positively affect boreal tree growth (Zhang et al., 2019), whereas large amounts of soil moisture may lead to overwetting conditions, resulting in reduced gross primary production (Kotani et al., 2019). In subarctic bogs, phenology observed by earlier flowering dates was reported in an experiment with an open top chamber (Aerts et al., 2004). On the other hand, earlier snow melt, followed by cold air temperatures, reduced productivity in Arctic Alaskan tundra (Stow et al., 2004) and boreal forests in northeastern Siberia (Kirdyanov et al., 2003). Models with coupled hydrological and biogeochemical processes (such as CHANGE) have also shown that deeper snow cover causes larger net ecosystem exchange because of higher soil moisture, especially during dry years (Park et al., 2011).

Snow plays an important role in controlling soil moisture and the nutrient balance because higher soil temperatures can activate the decomposition of soil organic matter, resulting in ecosystem changes (Schimel and Clein, 1996; Hardy et al., 2001; Robinson, 2002; Aerts, 2006). There have been many reports on the relationship between snow cover depth and soil nitrogen (e.g. Wipf and Rixen, 2010); however, these effects are vastly different and depend on ecosystem types, which is likely caused by differences in litter quality and quantity, microbial composition, plant $\mathrm{N}$ demand, or the response of soil moisture and soil temperature ( $\mathrm{Li}$ et al., 2016). Although nitrogen production and uptake by plants during winter are relatively well studied in temperate forests (Andresen and Michelsen, 2005; Ueda and Tokuchi, 2013), the number of studies in boreal and tundra ecosystems is still limited (Cooper, 2014; Koyama and Kielland, 2019). Kielland et al. (2006) described how earlier and deeper snowpacks in forest ecosystems allow microbial activity to continue during winter in Alaska, which was previously presumed to be biologically inactive due to a negative soil temperature. They also observed that winter (non-growing season) nitrogen mineralization accounted for approximately $40 \%$ of the annual flux, which was significantly higher than previously reported. Moreover, deeper snow cover causes higher soil nitrogen availability, which leads to 
increased plant $\mathrm{N}$ uptake, foliar nitrogen content, photosynthesis rates (Leffler and Welker, 2013), leaf area index (Pattison and Welker, 2014), and plant production (Wahren et al., 2005).

Frost damage is another factor associated with a decrease in snow cover depth. Thin snow cover may cause freeze-thaw cycles in winter and have a negative effect on plant production. The experimental removal of snow cover has previously produced direct frost damage, followed by a $50 \%$ reduction in understory vegetation coverage (Kreyling et al., 2012). Indirectly, soil frost and frequent freeze-thaw cycles in the absence of snow cover during winter and spring can cause a decrease in nitrogen availability (Feng et al., 2007, Frechette et al., 2011), an increase in nitrogen and phosphorus leaching (Fitzhugh et al., 2001), and root damage, which disrupts nutrient uptake (Cleavitt et al., 2008). Forests with deeper organic layers have a lower possibility of soil frost damage during winter, even if the snow cover is less deep (Hardy et al., 2001).

Although there have been many reports on snow manipulation experiments on tundra ecosystems, few reports have been published on forest ecosystems. This is because snow cover manipulation in forests is complicated by snow shoveling, unlike in tundra, where snow fences can be easily used to manipulate snow cover. In temperate and boreal forests, most snow manipulation experiments have been conducted in regions with expected reductions in snow, for example, North America and Scandinavia, and were mainly focused on the snow removal treatment (e.g. Groffman et al., 2001). Snow removal experiments in forested areas have shown a strong effect of snow cover on ecosystem processes, such as heat and moisture fluxes, nutrient dynamics, and changes in phenology and diversity (Groffman et al., 2001; Frechette et al., 2011; Kreyling et al., 2012; Comerford et al., 2013; Drescher and Thomas, 2013; Martz et al., 2016). Because of direct frost damage to the root system, there have been many reports on the reduced ability of plants to uptake water and nutrients (Pilon et al., 1994; Cleavitt et al., 2008; BlumeWerry et al., 2016). A decrease in nutrient availability from shallower snow cover due to leaching or impaired microbial activity has also been reported (Fitzhugh et al., 2001). Moreover, Frechette et al. (2011) observed decreases in foliar $\mathrm{N}$ and photosynthetic activity through spring snow removal in a Canadian boreal forest ecosystem. Other effects have also been observed, such as reductions in the terminal shoot length of sugar maple trees in the U.S. (Comerford et al., 2013), a decrease in the coverage of understory plants in Swedish boreal forests (Kreyling et al., 2012), and reductions in sapling survival in forests in Canada and northern Finland (Drescher and Thomas, 2013; Martz et al., 2016). These effects have negative implications for biomass production. As described above, there are many publications on Alaska and European boreal and temperate forest ecosystems; however, no snow manipulation experiments have been conducted for taiga (deciduous conifer larch forests) in northeastern Siberia, which is a globally typical forest ecosystem because of its extremely large area.

Eastern Siberia is a vast territory covered by taiga, which is characterized by deciduous conifer larch trees (Larix gmelinii and L. cajanderi) that grow on permafrost (Archibold, 1995). This region experiences extreme cold winters, short and hot summers, and an extremely dry climate. Because of the vast coverage area of larch forests worldwide (approximately $40 \%$ of boreal forests), the response of larch forests is extremely important. Changes in the snow cover depth and snow water equivalent (SWE) in this region 
affect soil moisture considerably. For larch trees, soil moisture derived from snowmelt water is extremely important in the early summer season when photosynthesis activity is highest (Sugimoto et al., 2002, 2003). It is also expected that larch trees will be affected by changing snow cover and the related processes described above. Nevertheless, there have been no reports of snow manipulation experiments for larch forests in northeastern Siberia. Therefore, the objective of this research is to observe the responses of larch trees to changes in snow cover using snow manipulation experiments.

In this study, we employ two types of treatments: snow addition (SNOW+) and snow removal (SNOW-), and hypothesize that these treatments will have opposing effects (Fig. 1). Specifically, when the depth of "snow cover increases (decreases)", snowmelt is delayed (advanced), which causes a "shorter (longer) growing season", resulting in a "decrease (increase) in production". If the soil moisture is unusually high after snowmelt, this situation may cause "overwetting in early summer (dry condition)" due to a large (small) amount of snowmelt water, which may consequently lead to "forest dieback (drought) " and resulting in decrease in production. Indeed, an extreme wetting events occurred in 2006-2007 in the taiga forest ecosystem near Yakutsk, which is usually a very dry forest (Iwasaki et al., 2010; Tei and Sugimoto, 2018; Tei et al., 2013, 2017). Moreover, we hypothesize that "snow cover increase (decrease)" also affect nutrient and water availability (Fig. 1). First, an "increase (decrease) in the depth of snow cover" causes "higher (lower) soil temperature during winter", leading to "higher (lower) microbial activity" and "higher (lower) nitrogen availability". This may cause an "increase (decrease) in production". Second, an "increase (decrease) in snow cover" will induce "larger (smaller) infiltration of snow meltwater", resulting in "higher (lower) water availability" and an "higher (lower) photosynthesis rate". This may cuase finally an "increase (decrease) in forest production". Both soil moisture and soil nutrients are limiting factors for forest photosynthetic activity at the study site (Popova et al., 2013; Tei et al. 2013).

To determine the effect of snow cover changes on the Eastern Siberia larch forest ecosystem, a snow manipulation experiment was conducted in December 2015 by manually removing snow from the snow removal plot (SNOW-) by shovels and adding the removed snow to the snow addition plot (SNOW+) by transporting it in heavy duty bags. The aim of this study is to examine whether the manipulated snow cover affects soil temperature and soil moisture via changes in insulation properties and melt timing, which in turn could affect soil nutrients and soil water availability, thereby affecting the timing of needle opening and leaf chemistry. We expect that these effects will cause a change in tree production. As no direct measurements of production change are conducted in this study, we instead employ the following measurements: 1) needle elongation measurements as a proxy for the growing season length, which can be used as a proxy for production change; 2 ) soil nutrient availability and foliar $\mathrm{N} \%$, which can also be used as a proxy for the photosynthesis rate, which has an effect on production; and 3) soil moisture measurements. As soil moisture is an important limiting factor for production in very dry regions, the inclusion of such measurements in snow manipulation experiments should be considered in future research.

\section{Methods}


The experiment was conducted at Spasskaya Pad Scientific Forest Station $\left(62^{\circ} 25^{\prime} \mathrm{N}, 129^{\circ} 62^{\prime} \mathrm{E}\right.$, elevation $220 \mathrm{~m}$ above sea level) of the Institute for Biological Problems of Cryolithozone, Siberian Branch of the Russian Academy of Sciences (Fig. 2). The station is located 20 km northwest of Yakutsk, Sakha Republic, Russian Federation (Fig. 2). Deciduous conifers (Larix cayanderi and L. gmelinii) are the dominant species in the study area. This region is characterized by an intense continental climate with severe cold winters and hot dry summers with an extreme range of monthly mean temperatures from +19 ${ }^{\circ} \mathrm{C}$ in July to $-40{ }^{\circ} \mathrm{C}$ in January. The average annual mean precipitation is $238 \mathrm{~mm}$ (from 1971 to 2000) and the average maximum snow cover depth is $34 \pm 7 \mathrm{~cm}$ (from 1959 to 2015), according to observations at Yakutsk station of the Hydrometeorological Center of Russia.

\section{Experimental design}

During the summer of 2015 , three $20 \mathrm{~m} \times 20 \mathrm{~m}\left(400 \mathrm{~m}^{2}\right)$ experimental plots for snow addition (SNOW+), snow removal (SNOW-), and no treatment (CONTROL) were established (Fig. 2C). Snow cover at the SNOW- plot was manually removed using shovels and transported to the SNOW+ plot in heavy duty bags on December 17-21, 2015. At the time of manipulation, the snow depth was $24 \mathrm{~cm}$. After transporting the snow, the SNOW- plot had approximately $1 \mathrm{~cm}$ of snow cover remaining, and the snow cover depth of the SNOW + plot did not change because of compaction of existing snow cover by the added snow. Soil temperature and soil moisture observations were conducted from August 2015 to August 2016. In spring, the snow depth and snowmelt timing were recorded using automatic time-lapse cameras. During the growing season, needle elongation and thaw layer thickness were measured manually.

\section{Hydrometeorological observations}

Air temperature and precipitation were observed using an automatic weather observation system (WXT520, Vaisala, Vantaa, Finland) installed at a height of 15m (the top of the canopy). Soil moisture was observed with dielectric permittivity probes with data loggers (HS10 with EM50 data logger, Decagon Devices, Pullman, Washington, USA) installed at five depths of $0.01,0.1,0.2,0.3$ and $0.5 \mathrm{~m}$ at the SNOWand SNOW+ plots. Measurements began on June 4, 2015. Soil temperature measurements began on July 15,2015 , using thermistors (TMC-HD with U-12-008 data loggers (HOBO, Onset Computer Corporation, Bourne, Massachusetts, USA) at six depths of $0.1,0.2,0.4,0.6,0.8$, and $1 \mathrm{~m}$ for SNOW- and SNOW+

plots. The date of snowmelt was determined at all treatment plots using images from a time-lapse camera according to the date at which $50 \%$ of the ground surface was visible.

\section{Needle elongation and samplings}

Three typical young larch trees (2-4 m height) were selected from each treatment type for needle elongation measurement and sampling for foliar chemistry analysis $(\mathrm{C} \%, \mathrm{~N} \%$, and their isotopic composition). Three branches at each selected tree were marked, and the elongation of 3-9 randomly selected needles was measured at each branch using digital calipers. Needle length measurements were 
conducted seven times from May 8 to July 8, 2016. Needles were also sampled on June 17, July 16, and August 20,2016, and current year shoots were sampled on August 20, 2016 for carbon and nitrogen content and isotope analyses. Dried needles and shoots were ground and analyzed with an elemental analyzer - mass spectrometer online system (Flash EA 1112 and Delta V, Thermo Fisher Scientific, Massachusetts, USA). The analytical accuracy (reproducibility) was $0.3 \%$ and $0.2 \%$ for carbon and nitrogen content, respectively, and less than $0.2 \%$ o for $\delta^{13} \mathrm{C}$ and $\delta^{15} \mathrm{~N}$.

To analyze the isotopic composition of stem water, we selected branches from mature trees in order to minimize the possible effects of sampling damage on the growth of young trees in the needle elongation observations and foliar chemistry analysis. Tree branches from two mature larch trees (reaching stand height) at each treatment plot were sampled from 4-6 m height using an extendable tree pruner. Bark and cambium were removed and the remaining xylem was cut into $1-\mathrm{cm}$ pieces, stored in glass vials, and stored at $-18{ }^{\circ} \mathrm{C}$ prior to extraction. Branch samples were collected on May 14, May 27, June 7, June 15, July 16, and August 12, 2015, and on May 29, June 17, July 15, and August 14, 2016. Water was extracted from the stem cryogenically on a vacuum distillation line and stored in glass vials at $5{ }^{\circ} \mathrm{C}$ prior to analysis. Rain samples were collected during rain events in situ using a simple rain collector. Snow cover samples were collected on December 16-19, 2015, using a metal cylinder (12-cm diameter). The water samples were analyzed using an online system (GasBench equipped with MAT253, Thermo Fisher Scientific, Massachusetts, USA). Analytical accuracy (reproducibility) was 0.2 and $0.1 \%$ for $\delta D$ and $\delta^{18} \mathrm{O}$, respectively.

\section{Soil inorganic nitrogen}

For the soil inorganic nitrogen analysis, four soil core samples were collected from all treatment plots on July 16, July 25, and August 15, 2016, at four depths (organic layer, $0-10,10-20$, and 20-50 cm). Roots were removed from the soil samples, and soil nitrogen was immediately extracted from $4 \mathrm{~g}$ of soil sample by $40 \mathrm{ml}$ of $2 \mathrm{M} \mathrm{KCl}$ solution and mixed on a shaker ( $40 \mathrm{~min}$ ). The solution and soil particles were then separated using a centrifuge and filtrated with a $0.45-\mu \mathrm{m}$ syringe filter. The extracts were stored at $-18^{\circ} \mathrm{C}$ prior to analysis, and ammonium and nitrate concentrations in the extracted samples were analyzed using a continuous flow spectrophotometer autoanalyzer (Bran \& Luebbe, Norderstedt, Germany).

\section{Statistical analyses}

Statistical significance was analyzed using the Student's t-test for needle length and one-way ANOVA with post-hoc Tukey test for needle chemistry. Data were compared among treatments on the same date with a significance level of $p>0.05$.

\section{Results}

\subsection{Hydrometeorological conditions during the experiment}


Table 1 shows the monthly averages of air temperatures and precipitation during warm periods (April to September) as a seven-year average (2010-2016) and for 2015 and 2016. The air temperature of the years before and after snow manipulation (2015 and 2016, respectively) was close to the seven-year average, except for April $2015\left(-6.3^{\circ} \mathrm{C}\right)$ and September $2016\left(7.9^{\circ} \mathrm{C}\right)$, which were colder and warmer than the seven-year average $\left(-0.6\right.$ and $\left.4.7^{\circ} \mathrm{C}\right)$, respectively. Total precipitation during the warm period in 2015 and 2016 was mostly similar to the seven-year average $(119,109$, and $109 \mathrm{~mm}$, respectively); however, June 2015 showed a larger amount of rainfall, and August 2015 and September 2016 received smaller amounts of rain than the seven-year average. Before snow manipulation on December 17-21, 2015, the snow density was $106 \mathrm{~kg} / \mathrm{m}^{3}$ with snow water equivalent (SWE) of $25 \mathrm{~mm}$.

Before snow manipulation, soil temperatures of all three plots exhibited no significant difference, except for lower values at $0.1 \mathrm{~m}$ and $0.2 \mathrm{~m}$ depth at CONTROL from October to December (Fig. 3). After manipulation, the soil temperature in the SNOW- plot rapidly decreased and became significantly lower than that in the SNOW+ and CONTROL plots. The maximum difference between SNOW- and CONTROL was $5.8^{\circ} \mathrm{C}$ at $0.1 \mathrm{~m}$ on December 30,2015 , and this difference decreased with depth. The difference between SNOW+ and CONTROL was $3.7^{\circ} \mathrm{C}$ at $0.1 \mathrm{~m}$ on the same date. At the end of March, as the daytime air temperature increased, the soil temperature started to increase simultaneously for all treatments. No significant difference in soil temperature was observed among the three plots during the period from March 24 to April 18, 2016. However, after snow melt started on April 19 at the SNOWplot (Fig. 4a and b), the soil temperature of all monitored soil depths (from $0.1 \mathrm{~m}$ to $1 \mathrm{~m}$ ) became higher than the soil temperature at the CONTROL plot at corresponding depths. This may be caused by a difference in soil moisture, as described below. The observed difference in soil temperature continued until the end of the observation period. The soil temperature difference between SNOW+ and CONTROL was much smaller than that between SNOW- and CONTROL after snowmelt. The soil temperature at 0.1 $\mathrm{m}$ depth in the SNOW- plot exceeded $0{ }^{\circ} \mathrm{C}$ on April 27 (eight days after snowmelt), and exhibited diurnal fluctuations for 12 days (until May 10), decreasing to almost $0{ }^{\circ} \mathrm{C}$ during nighttime (Fig. 4a), which indicates diurnal freeze-thaw cycles. However, soil temperature at $0.1 \mathrm{~m}$ depth in the SNOW+ plot only exceeded $0{ }^{\circ} \mathrm{C}$ on May 16 (20 days after snowmelt), and showed diurnal variations with minimum soil temperatures at or below $0{ }^{\circ} \mathrm{C}$ for only seven consecutive days (until May 23).

Before snow manipulation, there was no significant difference in the average soil thaw depth between SNOW+ $(58 \pm 13 \mathrm{~cm})$ and SNOW- $(61 \pm 13 \mathrm{~cm})$ plots $(\mathrm{n}=441)$ on July 7,2015 , indicating similar soil properties between the two plots. However, the spatial variability of soil thaw depth showed a dependency on understory vegetation. Under patches of deciduous shrubs with broader leaves (Arctous alpina), thethaw depth was shallower than that under patches of evergreen shrubs (Vaccinium vitis-idaea, Arctostaphylos uva-ursi) and grasses due to shading by the higher leaf area.

After snow manipulation, in the summer of 2016, thaw depth was measured only for designated subplots $\left(9 \mathrm{~m}^{2}\right)$ with a dominant type of understory plant (deciduous shrub, evergreen shrub, grasses). On July 26, 2016, SNOW- subplots had the deepest average thaw depth, whereas SNOW+ subplots were the shallowest, and CONTROL subplots exhibited intermediate thaw depths. The average thaw layer depths 
of the three subplots were $84 \pm 9 \mathrm{~cm}$ for SNOW-, $72 \pm 6.7 \mathrm{~cm}$ for SNOW+, and $77 \pm 5.3 \mathrm{~cm}$ for CONTROL. As the soil thawed in the summer of 2016, soil moisture was higher at SNOW+ than SNOWin the surface soil layers $(0.1 \mathrm{~m}$ and $0.3 \mathrm{~m})$ (Fig. 4c) due to the infiltration of snowmelt water.

\subsection{Snowmelt timing and needle elongation}

The snowmelt date occurred earliest in the SNOW- plot (April 19), followed by CONTROL (April 23), then SNOW+ (April 25), as shown in Fig. 5. Leaf opening of young larch trees in all three plots already started on May 8, 2016, at the beginning of the observation period (Fig. 6). Despite the earlier snowmelt, SNOWplot needles exhibited delayed elongation, with a shorter length on May $8(1.56 \pm 0.46 \mathrm{~mm})$ than those of CONTROL $(2.58 \pm 0.86 \mathrm{~mm})$ and SNOW+ $(3.16 \pm 0.72 \mathrm{~mm})$ (Fig. 6). In the early growing season until May 30 , the needle length of SNOW+ was larger than that of SNOW-. In June and July, the observed needle length was also longer at SNOW+ than SNOW-, although, no statistical difference was observed because of the large variations in observed needle lengths. In the SNOW+ and CONTROL plots, the needles continued to elongate until May 30, with no statistically significant change in needle lengths in June and July. Conversely, in the SNOW- plot, needles continued to elongate from May 30 to June $16(p<0.05)$.

\subsection{Stem water isotopic composition}

Before snow manipulation, in the summer of 2015 , the $\delta^{18} \mathrm{O}$ of larch stem water showed clear seasonal variations and no difference among three plots were observed (Fig. 7a). The $\delta^{18} \mathrm{O}$ values were highest in May $(-13.6 \%$ ) , with a sharp decrease in June $(-21.3 \%$ ), followed by an increase in July $(-16.5 \%$ ) and August $\left(-18.6 \%\right.$ ). After snow manipulation, in the summer of 2016 , the $\delta^{18} \mathrm{O}$ values of larch stem water showed clear differences among the three plots (Fig. 7b). The $\delta^{18} \mathrm{O}$ of the SNOW- plot exhibited the highest values throughout summer $(-18.5 \%$ ), with only a slight increase of $-1.3 \%$ o from June to August. CONTROL and SNOW+ plots exhibited similar values that were lower than those of SNOW- in early summer, but almost equal to those of SNOW- $(-18.1 \%$ in in August. As shown in Table 1 and Fig. 8 , summer rainfall has higher $\delta^{18} \mathrm{O}$ values than winter snow; thus, the decreased $\delta^{18} \mathrm{O}$ in all plots in June 2015 and in SNOW+ and CONTROL plots in 2016 resulted from the uptake of infiltrated snowmelt water, as previously described by Sugimoto et al. (2002).

\subsection{Carbon and nitrogen contents and isotopic ratios}

From June to August 2016, the carbon content of needles from young trees exhibited similar decreasing trends among all three plots with no significant differences (Fig. 9a). The $\delta^{13} \mathrm{C}$ values of all three plots also slightly decreased from June to August (Fig. 9b). The average SNOW+ $\delta^{13} \mathrm{C}$ value $(-29.9 \pm$ $0.5 \%$ o) was lower than that of SNOW- $(-29.4 \pm 0.4 \%$ o $)$ on June 17 , although this difference was not statistically significant. 
Needle nitrogen content at SNOW- decreased drastically from June $17(1.4 \pm 0.2 \%)$ to July $16(1.2 \pm$ $0.1 \%)$, whereas the average values at SNOW+ and CONTROL decreased slightly. Then, on August 20, the nitrogen content in all plots increased, especially in the SNOW- plot (Fig. 9c). The observed needle $\delta^{15} \mathrm{~N}$ value ranged from $-6.2 \%$ o to $-2.1 \%$, revealing large variability among individual trees. Needle $\delta{ }^{15} \mathrm{~N}$ values of most trees exhibited an increasing trend from June 17 to August 20, except for two of the three trees in the SNOW- plot. In the SNOW+ and CONTROL plots, the June to August increase in $\delta^{15} \mathrm{~N}$ values was $0.8 \%$.

At the SNOW- plot, the $\delta^{13} \mathrm{C}$ values of current year shoots $(-29.9 \pm 0.5 \%$ o) were similar to those of needles $\left(-29.9 \pm 0.3 \%\right.$ ) , which were higher than the $\delta^{13} \mathrm{C}$ values of current year shoots and needles at SNOW $+(-30.8 \pm 0.7 \%$ o and $-30.6 \pm 0.8 \%$ o, respectively $)$, although this difference was not statistically significant $(p>0.16$ for shoots and $p>0.28$ for needles) (Fig. 10).

\subsection{Soil inorganic nitrogen}

Soil inorganic nitrogen exhibited temporal and spatial variations at the study site (Fig. 11). Inorganic nitrogen, mostly comprised ammonium, rapidly increased from the middle of July to the middle of August. A low concentration of ammonium was found in the SNOW+ plot in the middle of July (Fig. 11a) and at the end of July (Fig. 11b) the amount of ammonium increased in the SNOW+ and CONTROL plots. At the end of July, a low concentration of ammonium was observed at the SNOW- plot (Fig. 11b), and at the end of August concentration of ammonium at the SNOW- plot finally increased (Fig. 11c).

\section{Discussion}

\subsection{Soil temperature}

In our experiment, after snow manipulation, winter soil temperature in the SNOW- plot quickly decreased from that in SNOW+ and CONTROL (Fig. 3). The absence of a snowpack at the SNOW-plot during the coldest period in winter reduced the effect of snowpack insulation and we expect a higher thermal conductivity of the ground surface, including the snowpack, enabling winter cold waves to cool the deep soil layer. Therefore, because of the lower snowpack depth and higher thermal conductivity, the SNOWplot showed lower soil temperatures until March, when air temperature rose substantially.

Generally, cold regions such as Yakutsk have lower snow water equivalent (SWE) and snow density (108 $\mathrm{kg} / \mathrm{m}^{3}$ in winter and $161 \mathrm{~kg} / \mathrm{m}^{3}$ in spring, as measured in 2015 at the experimental site), which suggests a higher thermal conductivity of the ground surface, including the snowpack. Conversely, we expect deeper snow conditions to correspond to a smaller thermal conductivity. The SNOW+ plot showed higher soil temperatures than the CONTROL plot until mid-January, however, during the period from mid-January to March, the soil temperature was similar in SNOW+ and CONTROL (Fig. 3). This similarity may have been caused by compaction of the snowpack. After manipulation, the observed snow depth at SNOW+ was $24 \mathrm{~cm}$, which was similar to that before manipulation, because the snow density was doubled by 
adding snow from the SNOW- plot. Thus, compaction of the snowpack may impair the insulation effect of the snowpack (Zhang, 2005).

\subsection{Length of growing season}

The SNOW- plot experienced earlier snowmelt (April 19) than the SNOW+ and CONTROL plots (April 25 and 23), as shown in Fig. 5. However, contrary to our hypotheses in Fig. 1, the SNOW- plot did not exhibit earlier needle opening, with delayed needle elongation observed instead (Fig. 6). Needle opening started before the first day of our observation (May 8, 2015). During the period from May 8 to May 30, needle length in the SNOW- plot was significantly shorter than that in the SNOW+ and CONTROL plots, where needle elongation continued until May 30. On the other hand, needles at the SNOW- plot continued to elongate until June 16. Clearly, needle elongation took longer at the SNOW- plot. One of the possible reasons for this is the dry conditions (Fig. 1). The limited water supply at the SNOW-plot during early summer may also be a factor influencing slower needle elongation (Fig. 4c). In the following subsection, we discuss the influence of soil moisture.

In contrast to these findings, previous studies have found that earlier snowmelt leads to a longer growing season. According to satellite and ground observation data, Barichivich et al. (2013) showed that photosynthesis activities in northern ecosystems are enhanced by the longer growing season, especially by earlier snowmelt and an earlier spring. Moreover, Sutinen et al. (2015) conducted a snow manipulation experiment and showed that soil frost in spring caused a delay in needle and shoot growth in Norway spruce. These results, which have generally been discussed as earlier snowmelt resulting in a longer growing season, seem different from ours. The small amount of precipitation (approximately $238 \mathrm{~mm}$ per year) at our study site (Yakutsk) may explain the difference between our study and previous research. Another possibility not explicitly shown in Fig. 1 is that frost damage of fine roots caused by freeze-thaw cycles in spring (Fig. 4a) might cause a delay in needle elongation (Fig. 6) through a decline in water and nutrient uptake.

\subsection{Soil moisture}

In 2015 and 2016 at Spasskaya Pad, the precipitation values agreed with the seven-year average (Table 1). Therefore, our experiment was conducted in typical dry conditions, with no "overwetting" conditions in the forest after the snowmelt in 2016 spring (Fig. 1). The origin of water in the soil can be determined using water isotope values, as described by Sugimoto et al. (2002). Infiltration of larger amounts of snowmelt water in SNOW+ and CONTROL plots than in the SNOW-plot was recorded by the $\delta^{18} \mathrm{O}$ values of stem water (Fig. 7). In 2015, before snow manipulation, the $\delta^{18} \mathrm{O}$ values of stem water in the SNOWplot showed a sharp decrease from May to June due to uptake of isotopically lighter snowmelt water (Fig. 8), which was similar to the values in the SNOW+ and CONTROL plots (Fig. 7a). In 2016, after manipulation, the SNOW- plot showed no variation in $\delta^{18} \mathrm{O}$ values throughout the growing season, whereas the CONTROL and SNOW+ plots exhibited lower $\delta^{18} \mathrm{O}$ values than the SNOW- plot on June 17 and July 15 . This means that trees in the SNOW- plot were unable to use snowmelt water, which has 
lower $\delta^{18} O$ values (Fig. 8). During summer, rainwater with high $\delta^{18} O$ values recharged the soil, and in August, all plots showed similarly high $\delta^{18} \mathrm{O}$ values (Fig. 7). As seen in Fig. 4c, soil moisture in the SNOW- plot increased gradually from early summer.

As described previously, the SNOW- plot was dry in early summer. Another proxy for soil moisture is the $\delta^{13} \mathrm{C}$ values of current year shoots because carbon used for the production of current year shoots is mainly photosynthesized during the growing season (Kagawa et al., 2006; Li and Sugimoto, 2017). In the SNOW- plot, the $\delta^{13} \mathrm{C}$ values of current year shoots were relatively higher than those in the SNOW+ and CONTROL plots, which suggests dry conditions in the SNOW- plot, however, these values were not statistically significant because of the small number of samples (Fig. 10).

\subsection{Nitrogen availability}

As shown in Fig. 9c, on June 17 and July 16, the needle nitrogen content in the SNOW+ and CONTROL plots showed similar values, whereas that at SNOW- showed a large deviation on June 17, and the value on July 16 was significantly lower than those at the SNOW+ and CONTROL plots $(p<0.05)$. These results show that N uptake by trees at the SNOW- plot was insufficient in the first half of summer. However, on August 20, needle N content in the SNOW- plot increased to a value comparable to that of SNOW+ and CONTROL. Similar trends were also observed in the soil inorganic $\mathrm{N}$ data, as shown in Fig. 11.

Soil inorganic $\mathrm{N}$ in the SNOW+ plot was detected in the middle of July (Fig. 11a) and increased rapidly at the end of July (Fig. 11b), whereas that of the SNOW- plot only increased in August (Fig. 11C). Therefore, these results indicate that $\mathrm{N}$ availability in the SNOW- plot was low until mid-July, which may have led to lower needle nitrogen content in the SNOW- plot during this period. Subsequently, trees in the SNOWplot used soil inorganic nitrogen at the end of July and in August, and the needle nitrogen content in the SNOW- plot in August increased to roughly the same as that in the SNOW+ and CONTROL plots (Fig. 9c). Foliar ${ }^{15} \mathrm{~N}$ at SNOW+ and CONTROL (Fig. 9d) showed a gradual increase from June to August, which corresponds to an increase in soil inorganic $\mathrm{N}$ concentrations (Fig. 11). It should be noted that the soil temperature at the SNOW- plot was higher than that at the SNOW+ and CONTROL plots during the growing season (Fig. 4).

There are several possible reasons for the delayed increase in soil inorganic nitrogen availability at the SNOW- plot. One may be the freeze-thaw cycles in the SNOW- plot during the period from April 28 (the day when the soil temperature exceeded $0{ }^{\circ} \mathrm{C}$ ) to May 8 (the day when the soil temperature stopped decreasing to $0.1^{\circ} \mathrm{C}$ or lower during the night) (Fig. 4a), which may damage the microbial biomass in the soil and plant roots. Another reason may be the dry soil conditions in the first half of the summer (Fig. 4c and $7 b$ ). Under dry soil conditions, inactive microbial decomposition may lead to less available nitrogen at SNOW- plot, and the inactive uptake of $\mathrm{N}$ by plants causes low $\mathrm{N}$ contents in the needles. Extremely low soil temperature at the SNOW- plot during winter might affect the soil microbes and plant roots. An increase in nutrient availability with a manipulated increase in the snowpack was observed in a snow manipulation experiment in high Arctic Svalbard tundra, which led to an increase in stem nitrogen content 
and a positive growth response (Blok et al., 2015). Conversely, we observed an increase in leaf nitrogen content and faster needle growth. In our experiment, the manually decreased snowpack depth in the SNOW- plot delayed the start of the growing season due to colder winter soil temperatures with increased frequency of freeze-thaw cycles in spring and drier conditions in the first half of the summer, which delayed the production of soil inorganic nitrogen and the start of needle elongation and low foliar nitrogen content in June and July. Although it did not significantly alter the winter soil temperature at the SNOW+ plot, additional snow provided sufficient soil moisture in early summer and advanced the start of needle elongation.

\subsection{Comparison with another regions}

Our study site is located in a continuous permafrost zone with an extreme continental subarctic climate. It has extremely cold long winters with a small amount of snowfall and dry and hot short summers. Compared to other regions, it is a rather complex study area because it is as cold as high arctic tundra but as dry as alpine tundra, and contains abundant forests. Groffman et al. (2001) proposed a hypothesis whereby global warming will cause less snow cover during winter and therefore less thermal insulation, which will lead to the "colder soils in a warmer world" phenomenon. They conducted a snow removal experiment in a northern hardwood forest in the US and reported only mild soil freezing $\left(-4^{\circ} \mathrm{C}\right)$ in winter, indicating a greater potential for freeze-thaw cycles during winter. On the other hand, at our site, the soil in the CONTROL plot was frozen for more than three months and the soil temperature was below $-14{ }^{\circ} \mathrm{C}$. Moreover, the soil temperature at the SNOW- plot was less than $-19{ }^{\circ} \mathrm{C}$ soon after snow removal (Fig. 3). Such low temperatures could cause mechanical or cellular root damage. In our experiment, the production of soil ammonium at the SNOW- plot was delayed until the end of July (Fig. 11c). The low soil temperature at the SNOW- plot observed during winter might damage not only the roots but also the soil microbes. In addition, freeze-thaw cycles in spring (Fig. 4a) may also damage soil microbes. Owing to these problems, snow removal in the experiments caused a delay in needle elongation during the early growing season.

It has previously been reported that low spring soil temperatures affect the ecosystem. In a boreal forest in Finland, the bud burst of Norway spruce was delayed for two weeks in a spring frost experiment, in which insulation by $15 \mathrm{~cm}$ of hay was applied, resulting in prolonged soil frost (Sutinen et al, 2015). This indicates that spring soil frost affects the length of the growing season. In our experiment, we observed that earlier snowmelt at the SNOW- plot did not hasten needle flushing, but slowed needle elongation, although the soil temperature was higher than that at the CONTROL plot. This result contradicts the hypothesis of this study (Fig. 1), and differs from previous results in Finland boreal forests (Sutinen et al., 2015). Our study site is characterized by extremely low air temperature and dry conditions in winter, as well as a short snowmelt season. Therefore, it is very important for plants to obtain water instead of warming the soil during the needle flushing period.

\section{Conclusions}


A snow cover manipulation experiment was conducted in December 2015 at the Spasskaya Pad Scientific Forest Station in the Eastern Siberia taiga forest ecosystem. The snow removal (SNOW-) plot showed a more significant effect of manipulation than the other plots. Needle opening and shoot elongation were delayed in the SNOW- plot, despite earlier snowmelt and a higher soil temperature during the growing season. Production of soil inorganic nitrogen was also delayed in the SNOW- plot, and the larch needle nitrogen content was lower than that in other plots until July. Soil ammonium at the SNOW- plot was eventually produced in August, which resulted in a comparable needle nitrogen content to the other plots.

The study duration was only one year, however, we observed a clear response of larch trees to snow cover changes, including changes in phenology (needle opening and shoot elongation). Moreover, longer experiments may cause changes to the ecosystem, such as photosynthesis and production. It is also difficult to predict possible scenarios for long-term ecosystem change because other factors, such as overwetting or permafrost degradation, should also be assessed.

\section{Declarations}

\section{Availability of data and material}

Please contact author for data requests.

\section{Competing interests}

The authors declare that they have no competing interests.

\section{Funding}

This work was supported by GRENE Arctic Climate Change Research Project funded by the Ministry of Education, Culture, Sports, Science and Technology-Japan (MEXT), and Belmont Forum Arctic program COPERA project funded by Japan Science and Technology Agency.

\section{Authors' contributions}

RS conducted the experiments and wrote the manuscript, and $\mathrm{SH}$ analyzed the soil inorganic nitrogen. TM arranged the all processes for field works and AS designed the experiments, and wrote the manuscript.

\section{Acknowledgements}


We acknowledge Dr. A. Kononov, R. Petrov, E. Starostin, and the other members of the IBPC for supporting our fieldwork at Spasskaya Pad Scientific Forest Station, and H. Shimada and M. Borisov for their assistance in summer and winter fieldwork. We also thank Y. Hoshino, S. Nunohashi, H. Kudo, and A. Alekseeva for their support in laboratory work and logistics.

\section{References}

1. Aerts R (2006) The freezer defrosting: global warming and litter decomposition rates in cold biomes. Journal of Ecology 94(4): 713-724. doi:10.1111/j.1365-2745.2006.01142.x

2. Aerts R, Cornelissen JHC, Dorrepaal E, van Logtestijn RSP, Callaghan TV (2004) Effects of experimentally imposed climate scenarios on flowering phenology and flower production of subarctic bog species. Global Change Biology 10(9): 1599-1609. doi:10.1111/j.13652486.2004.00815.x

3. Andresen LC, Michelsen A (2005) Off-season uptake of nitrogen in temperate heath vegetation. Oecologia 144(4): 585-597. doi:10.1007/s00442-005-0044-1

4. Archibold OW (1995) Ecology of world vegetation. Chapman \& Hall, London.

5. Barichivich J, Briffa KR, Myneni RB, Osborn TJ, Melvin TM, Ciais P, Piao SL, Tucker C (2013) Largescale variations in the vegetation growing season and annual cycle of atmospheric CO2 at high northern latitudes from 1950 to 2011. Global Change Biology 19(10): 3167-3183. doi:10.1111/gcb.12283

6. Blume-Werry G, Kreyling J, Laudon H, Milbau A (2016) Short-term climate change manipulation effects do not scale up to long-term legacies: effects of an absent snow cover on boreal forest plants. Journal of Ecology 104(6): 1638-1648. doi:10.1111/1365-2745.12636

7. Bulygina ON, Groisman PY, Razuvaev VN, Korshunova NN (2011) Changes in snow cover characteristics over Northern Eurasia since 1966. Environmental Research Letters 6(4). doi:10.1088/1748-9326/6/4/045204

8. Bulygina ON, Razuvaev VN, Korshunova NN (2009) Changes in snow cover over Northern Eurasia in the last few decades. Environmental Research Letters 4(4). doi:10.1088/1748-9326/4/4/045026

9. Callaghan TV, Johansson M, Brown RD, Groisman PY, Labba N, Radionov V, Barry RG, Bulygina ON, Essery RLH, Frolov DM, Golubev VN, Grenfell TC, Petrushina MN, Razuvaev VN, Robinson DA, Romanov P, Shindell D, Shmakin AB, Sokratov SA, Warren S, Yang DQ (2011) The Changing Face of Arctic Snow Cover: A Synthesis of Observed and Projected Changes. Ambio 40: 17-31. doi:10.1007/s13280-011-0212-y

10. Chapin FS, McGuire AD, Randerson J, Pielke R, Baldocchi D, Hobbie SE, Roulet N, Eugster W, Kasischke E, Rastetter EB, Zimov SA, Running SW (2000) Arctic and boreal ecosystems of western North America as components of the climate system. Global Change Biology 6: 211-223. doi:10.1046/j.1365-2486.2000.06022.x 
11. Cleavitt NL, Fahey TJ, Groffman PM, Hardy JP, Henry KS, Driscoll CT (2008) Effects of soil freezing on fine roots in a northern hardwood forest. Canadian Journal of Forest Research-Revue Canadienne De Recherche Forestiere 38(1): 82-91. doi:10.1139/x07-133

12. Comerford DP, Schaberg PG, Templer PH, Socci AM, Campbell JL, Wallin KF (2013) Influence of experimental snow removal on root and canopy physiology of sugar maple trees in a northern hardwood forest. Oecologia 171(1): 261-269. doi:10.1007/s00442-012-2393-x

13. Cooper EJ (2014) Warmer Shorter Winters Disrupt Arctic Terrestrial Ecosystems. In: Futuyma DJ (ed) Annual Review of Ecology, Evolution, and Systematics, Vol 45. Annual Review of Ecology Evolution and Systematics. Annual Reviews, Palo Alto. p 271-+

14. Deser C, Tomas R, Alexander M, Lawrence D (2010) The Seasonal Atmospheric Response to Projected Arctic Sea Ice Loss in the Late Twenty-First Century. Journal of Climate 23(2): 333-351. doi:10.1175/2009jcli3053.1

15. Drescher M, Thomas SC (2013) Snow cover manipulations alter survival of early life stages of coldtemperate tree species. Oikos 122(4): 541-554. doi:10.1111/j.1600-0706.2012.20642.x

16. Feng XJ, Nielsen LL, Simpson MJ (2007) Responses of soil organic matter and microorganisms to freeze-thaw cycles. Soil Biology \& Biochemistry 39(8): 2027-2037. doi:10.1016/j.soilbio.2007.03.003

17. Fitzhugh RD, Driscoll CT, Groffman PM, Tierney GL, Fahey TJ, Hardy JP (2001) Effects of soil freezing disturbance on soil solution nitrogen, phosphorus, and carbon chemistry in a northern hardwood ecosystem. Biogeochemistry 56(2): 215-238. doi:10.1023/a:1013076609950

18. Frechette E, Ensminger I, Bergeron Y, Gessler A, Berninger F (2011) Will changes in root-zone temperature in boreal spring affect recovery of photosynthesis in Picea mariana and Populus tremuloides in a future climate? Tree Physiology 31(11): 1204-1216. doi:10.1093/treephys/tpr102

19. Freppaz M, Pintaldi E, Magnani A, Viglietti D, Williams MW (2018) Topsoil and snow: a continuum system. Applied Soil Ecology 123: 435-440. doi:10.1016/j.apsoil.2017.06.029

20. Grippa M, Kergoat L, Le Toan T, Mognard NM, Delbart N, L'Hermitte J, Vicente-Serrano SM (2005) The impact of snow depth and snowmelt on the vegetation variability over central Siberia. Geophysical Research Letters 32(21): doi:10.1029/2005gl024286

21. Groffman PM, Driscoll CT, Fahey TJ, Hardy JP, Fitzhugh RD, Tierney GL (2001) Colder soils in a warmer world: A snow manipulation study in a northern hardwood forest ecosystem.

Biogeochemistry 56(2): 135-150. doi:10.1023/a:1013039830323

22. Hardy JP, Groffman PM, Fitzhugh RD, Henry KS, Welman AT, Demers JD, Fahey TJ, Driscoll CT, Tierney GL, Nolan S (2001) Snow depth manipulation and its influence on soil frost and water dynamics in a northern hardwood forest. Biogeochemistry 56(2): 151-174.

doi:10.1023/a:1013036803050

23. Huntington TG (2006) Evidence for intensification of the global water cycle: Review and synthesis. Journal of Hydrology 319(1-4): 83-95. doi:10.1016/j.jhydrol.2005.07.003

24. lijima Y, Fedorov AN, Park H, Suzuki K, Yabuki H, Maximov TC, Ohata T (2010) Abrupt Increases in Soil Temperatures following Increased Precipitation in a Permafrost Region, Central Lena River 
Basin, Russia. Permafrost and Periglacial Processes 21(1): 30-41. doi:10.1002/ppp.662

25. Iwasaki H, Saito H, Kuwao K, Maximov TC, Hasegawa S (2010) Forest decline caused by high soil water conditions in a permafrost region. Hydrology and Earth System Sciences 14(2): 301-307. doi:10.5194/hess-14-301-2010

26. Johansson M, Callaghan TV, Bosio J, Akerman HJ, Jackowicz-Korczynski M, Christensen TR (2013) Rapid responses of permafrost and vegetation to experimentally increased snow cover in sub-arctic Sweden. Environmental Research Letters 8(3). doi:10.1088/1748-9326/8/3/035025

27. Kagawa A, Sugimoto A, Maximov TC (2006) Seasonal course of translocation, storage and remobilization of C-13 pulse-labeled photoassimilate in naturally growing Larix gmelinii saplings. New Phytologist 171(4): 793-804. doi:10.1111/j.1469-8137.2006.01780.x

28. Karjalainen O, Luoto M, Aalto J, Hjort J (2019) New insights into the environmental factors controlling the ground thermal regime across the Northern Hemisphere: a comparison between permafrost and non-permafrost areas. Cryosphere 13(2): 693-707. doi:10.5194/tc-13-693-2019

29. Kielland K, Olson K, Ruess RW, Boone RD (2006) Contribution of winter processes to soil nitrogen flux in taiga forest ecosystems. Biogeochemistry 81(3): 349-360. doi:10.1007/s10533-006-9045-3

30. Kirdyanov A, Hughes M, Vaganov E, Schweingruber F, Silkin P (2003) The importance of early summer temperature and date of snow melt for tree growth in the Siberian Subarctic. Trees-Structure and Function 17(1): 61-69. doi:10.1007/s00468-002-0209-z

31. Kotani A, Saito A, Kononov AV, Petrov RE, Maximov TC, lijima Y, Ohta T (2019) Impact of unusually wet permafrost soil on understory vegetation and $\mathrm{CO} 2$ exchange in a larch forest in eastern Siberia. Agricultural and Forest Meteorology 265: 295-309. doi:10.1016/j.agrformet.2018.11.025

32. Koyama LA, Kielland K (2019) Black spruce assimilates nitrate in boreal winter. Tree Physiology 39(4): 536-543. doi:10.1093/treephys/tpy109

33. Kreyling J, Haei M, Laudon $H$ (2012) Absence of snow cover reduces understory plant cover and alters plant community composition in boreal forests. Oecologia 168(2): 577-587. doi:10.1007/s00442-011-2092-z

34. Leffler AJ, Welker JM (2013) Long-term increases in snow pack elevate leaf $\mathrm{N}$ and photosynthesis in Salix arctica: responses to a snow fence experiment in the High Arctic of NW Greenland. Environmental Research Letters 8(2). doi:10.1088/1748-9326/8/2/025023

35. Li F, Sugimoto A (2018) Effect of waterlogging on carbon isotope discrimination during photosynthesis in Larix gmelinii. Isotopes in Environmental and Health Studies 54(1): 63-77. doi: 10.1080/10256016.2017.1340886

36. Li WB, Wu JB, Bai E, Guan DX, Wang AZ, Yuan FH, Wang SQ, Jin CJ (2016) Response of terrestrial nitrogen dynamics to snow cover change: A meta-analysis of experimental manipulation. Soil Biology \& Biochemistry 100: 51-58. doi:10.1016/j.soilbio.2016.05.018

37. Loranty MM, Abbott BW, Blok D, Douglas TA, Epstein HE, Forbes BC, Jones BM, Kholodov AL, Kropp H, Malhotra A, Mamet SD, Myers-Smith IH, Natali SM, O'Donnell JA, Phoenix GK, Rocha AV, Sonnentag O, Tape KD, Walker DA (2018) Reviews and syntheses: Changing ecosystem influences on 
soil thermal regimes in northern high-latitude permafrost regions. Biogeosciences 15(17): 5287-5313. doi:10.5194/bg-15-5287-2018

38. Martz F, Vuosku J, Ovaskainen A, Stark S, Rautio P (2016) The Snow Must Go On: Ground Ice Encasement, Snow Compaction and Absence of Snow Differently Cause Soil Hypoxia, $\mathrm{CO} 2$ Accumulation and Tree Seedling Damage in Boreal Forest. Plos One 11(6). doi:10.1371/journal.pone.0156620

39. Morse PD, Burn CR, Kokelj SV (2012) Influence of snow on near-surface ground temperatures in upland and alluvial environments of the outer Mackenzie Delta, Northwest Territories. Canadian Journal of Earth Sciences 49(8): 895-913. doi:10.1139/e2012-012

40. Nauta AL, Heijmans MMPD, Blok D, Limpens J, Elberling B, Gallagher A, Li B X, Petrov RE, Maximov TC, van Huissteden J, Berendse F (2015) Permafrost collapse after shrub removal shifts tundra ecosystem to a methane source. Nature Climate Change 5(1): 67-70. doi: 10.1038/nclimate2446

41. Park H, Fedorov AN, Zheleznyak MN, Konstantinov PY, Walsh JE (2015) Effect of snow cover on panArctic permafrost thermal regimes. Climate Dynamics 44(9-10): 2873-2895. doi:10.1007/s00382014-2356-5

42. Park H, lijima Y, Yabuki H, Ohta T, Walsh J, Kodama Y, Ohata T (2011) The application of a coupled hydrological and biogeochemical model (CHANGE) for modeling of energy, water, and $\mathrm{CO} 2$ exchanges over a larch forest in eastern Siberia. Journal of Geophysical Research-Atmospheres 116. doi:10.1029/2010jd015386

43. Park H, Sherstiukov AB, Fedorov AN, Polyakov IV, Walsh JE (2014) An observation-based assessment of the influences of air temperature and snow depth on soil temperature in Russia. Environmental Research Letters 9(6). doi:10.1088/1748-9326/9/6/064026

44. Pattison RR, Welker JM (2014) Differential ecophysiological response of deciduous shrubs and a graminoid to long-term experimental snow reductions and additions in moist acidic tundra, Northern Alaska. Oecologia 174(2): 339-350. doi:10.1007/s00442-013-2777-6

45. Pilon CE, Cote B, Fyles JW (1994) Effect of snow removal on leaf water potential, soil-moisture, leaf and soil nutrient status and leaf peroxidase-activity of sugar maple. Plant and Soil 162(1): 81-88. doi:10.1007/bf01416092

46. Popova AS, Tokuchi N, Ohte N, Ueda MU, Osaka K, Maximov TC, Sugimoto A (2013) Nitrogen availability in the taiga forest ecosystem of northeastern Siberia. Soil Science and Plant Nutrition 59(3): 427-441. doi: 10.1080/00380768.2013.772495

47. Robinson $\mathrm{CH}$ (2002) Controls on decomposition and soil nitrogen availability at high latitudes. Plant and Soil 242(1): 65-81. doi:10.1023/a:1019681606112

48. Schimel JP, Bilbrough C, Welker JA (2004) Increased snow depth affects microbial activity and nitrogen mineralization in two Arctic tundra communities. Soil Biology \& Biochemistry 36(2): 217227. doi:10.1016/j.soilbio.2003.09.008

49. Schimel JP, Clein JS (1996) Microbial response to freeze-thaw cycles in tundra and taiga soils. Soil Biology \& Biochemistry 28(8): 1061-1066. doi:10.1016/0038-0717(96)00083-1 
50. Stow DA, Hope A, McGuire D, Verbyla D, Gamon J, Huemmrich F, Houston S, Racine C, Sturm M, Tape K, Hinzman L, Yoshikawa K, Tweedie C, Noyle B, Silapaswan C, Douglas D, Griffith B, Jia G, Epstein H, Walker D, Daeschner S, Petersen A, Zhou LM, Myneni R (2004) Remote sensing of vegetation and land-cover change in Arctic Tundra Ecosystems. Remote Sensing of Environment 89(3): 281-308. doi:10.1016/j.rse.2003.10.018

51. Sugimoto A, Naito D, Yanagisawa N, Ichiyanagi K, Kurita N, Kubota J, Kotake T, Ohata T, Maximov TC, Fedorov AN (2003) Characteristics of soil moisture in permafrost observed in East Siberian taiga with stable isotopes of water. Hydrological Processes 17(6): 1073-1092. doi:10.1002/hyp.1180

52. Sugimoto A, Yanagisawa N, Naito D, Fujita N, Maximov TC (2002) Importance of permafrost as a source of water for plants in east Siberian taiga. Ecological Research 17(4): 493-503. doi:10.1046/j.1440-1703.2002.00506.x

53. Sutinen S, Roitto M, Repo T (2015) Vegetative buds, needles and shoot growth of Norway spruce are affected by experimentally delayed soil thawing in the field. Forest Ecology and Management 336: 217-223. doi:10.1016/j.foreco.2014.10.029

54. Tei S, Sugimoto A (2018) Time lag and negative responses of forest greenness and tree growth to warming over circumboreal forests. Global Change Biology 24(9):4225-4237. doi:

10.1111/gcb. 14135

55. Tei S, Sugimoto A, Liang MC, Yonenobu H, Matsuura Y, Osawa A, Sato H, Fujinuma J, Maximov T. (2017) Radial Growth and Physiological Response of Coniferous Trees to Arctic Amplification. Journal of Geophysical Research-Biogeosciences 122(11): 2786-2803. doi: 10.1002/2016jg003745

56. Tei S, Sugimoto A, Yonenobu H, Yamazaki T, Maximov TC (2013) Reconstruction of soil moisture for the past 100 years in eastern Siberia by using delta C-13 of larch tree rings. Journal of Geophysical Research-Biogeosciences 118(3): 1256-1265. doi: 10.1002/jgrg.20110

57. Ueda MU, Tokuchi N (2013) Effects of winter buds on winter nitrogen uptake and allocation in Pinus densiflora saplings. Journal of Forest Research 18(6): 462-465. doi:10.1007/s10310-012-0371-0

58. Vaughan, D.G., J.C. Comiso, I. Allison, J. Carrasco, G. Kaser, R. Kwok, P. Mote, T. Murray, F. Paul, J. Ren, E. Rignot, O. Solomina, K. Steffen and T. Zhang, 2013: Observations: Cryosphere. In: Climate Change 2013: The Physical Science Basis. Contribution of Working Group I to the Fifth Assessment Report of the Intergovernmental Panel on Climate Change [Stocker, T.F., D. Qin, G.-K. Plattner, M. Tignor, S.K. Allen, J. Boschung, A. Nauels, Y. Xia, V. Bex and P.M. Midgley (eds.)]. Cambridge University Press, Cambridge, United Kingdom and New York, NY, USA.

59. Vavrus S (2007) The role of terrestrial snow cover in the climate system. Climate Dynamics 29(1): 73-88. doi:10.1007/s00382-007-0226-0

60. Wahren CHA, Walker MD, Bret-Harte MS (2005) Vegetation responses in Alaskan arctic tundra after 8 years of a summer warming and winter snow manipulation experiment. Global Change Biology 11(4): 537-552. doi:10.1111/j.1365-2486.2005.00927.x

61. Walker MD, Walker DA, Welker JM, Arft AM, Bardsley T, Brooks PD, Fahnestock JT, Jones MH, Losleben M, Parsons AN, Seastedt TR, Turner PL (1999) Long-term experimental manipulation of 
winter snow regime and summer temperature in arctic and alpine tundra. Hydrological Processes 13(14-15): 2315-2330. doi:10.1002/(sici)1099-1085(199910)13:14/15<2315::aid-hyp888>3.0.co;2-a

62. Wipf S, Rixen C (2010) A review of snow manipulation experiments in Arctic and alpine tundra ecosystems. Polar Research 29(1): 95-109. doi:10.1111/j.1751-8369.2010.00153.x

63. Zhang TJ (2005) Influence of the seasonal snow cover on the ground thermal regime: An overview. Reviews of Geophysics 43(4). doi:10.1029/2004rg000157

64. Zhang XL, Manzanedo RD, D'Orangeville L, Rademacher TT, Li JX, Bai XP, Hou MT, Chen ZJ, Zou FH, Song FB, Pederson N (2019) Snowmelt and early to mid-growing season water availability augment tree growth during rapid warming in southern Asian boreal forests. Global Change Biology 25(10): 3462-3471. doi:10.1111/gcb.14749

\section{Tables}

Table 1. Monthly air temperature and precipitation.

\begin{tabular}{|c|c|c|c|c|c|c|c|c|}
\hline \multirow{2}{*}{ Month } & \multicolumn{3}{|c|}{ Air temperature $\left({ }^{\circ} \mathrm{C}\right)$} & \multicolumn{3}{|c|}{ Precipitation (mm) } & \multicolumn{2}{|c|}{$\begin{array}{c}\text { Precipitation } \\
\delta 180(\%)\end{array}$} \\
\hline & $\begin{array}{c}\text { 7-year } \\
\text { ave }\end{array}$ & 2015 & 2016 & $\begin{array}{c}\text { 7-year } \\
\text { ave }\end{array}$ & 2015 & 2016 & 2015 & 2016 \\
\hline Apr & -0.6 & -6.3 & 0.3 & 1.7 & 0.1 & 0.1 & - & - \\
\hline May & 8.1 & 6.2 & 7.0 & 10.8 & 12.6 & 10.7 & - & -18.1 \\
\hline Jun & 14.8 & 13.8 & 15.9 & 24.1 & 45.2 & 27.7 & - & -15.1 \\
\hline Jul & 19.9 & 18.5 & 17.6 & 32.7 & 28.8 & 41.8 & -10.0 & -14.5 \\
\hline Aug & 14.5 & 15.5 & 13.2 & 25.3 & 13.6 & 27.4 & -13.4 & - \\
\hline Sep & 4.7 & 4.3 & 7.9 & 14.1 & 18.4 & 1.1 & - & - \\
\hline
\end{tabular}

Monthly data in 2015 and 2016 and the seven-year average from 2010 to 2016 , and $\delta^{18} 0$ (\%o) values of precipitation in 2015 and 2016 observed at Spasskaya Pad during the warm period (April to September) were shown.

\section{Figures}




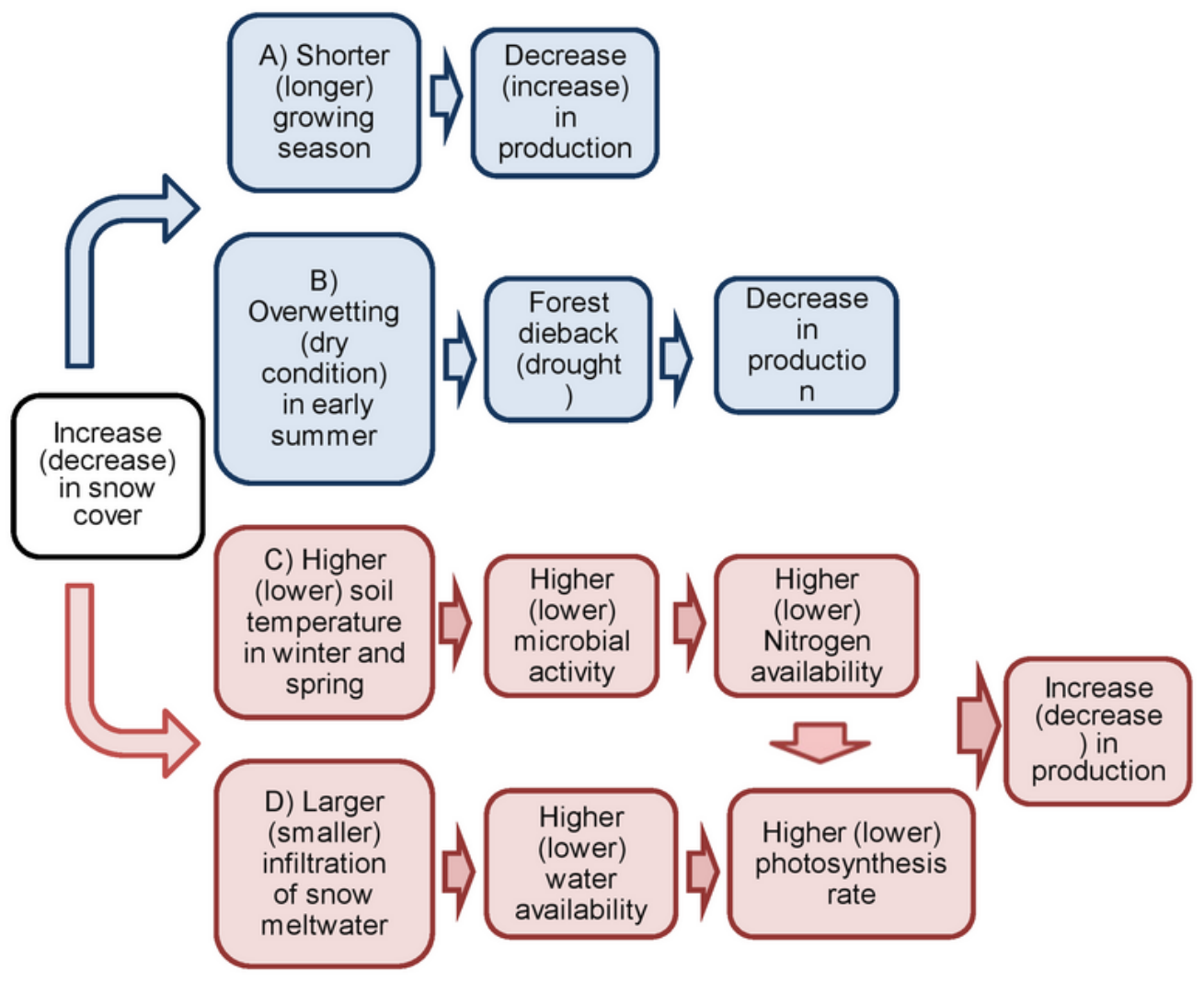

Figure 1. Working hypotheses for snow cover depth increase (or decrease) in the snow manipulation experiment.

\section{Figure 1}

See image above for figure legend. 


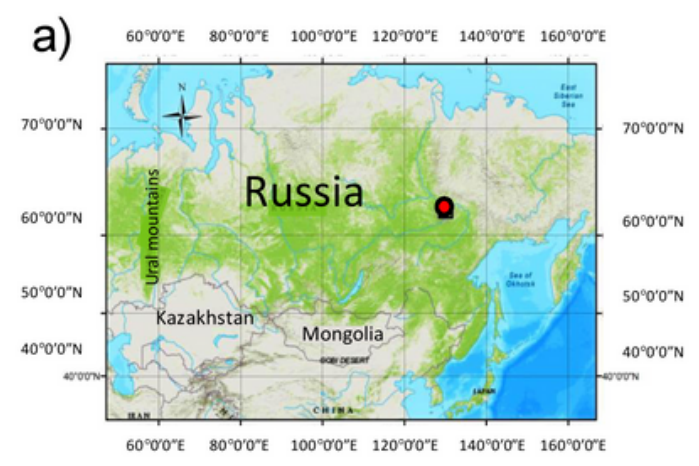

b)

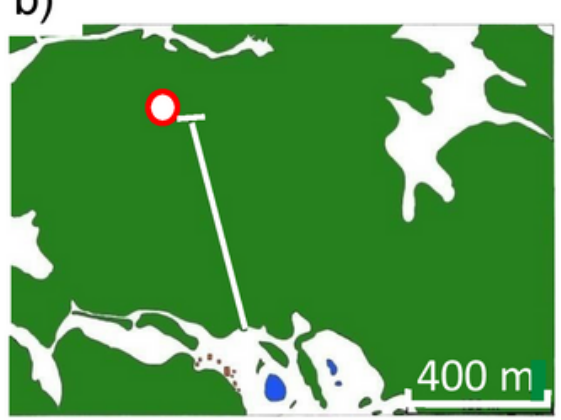

c)

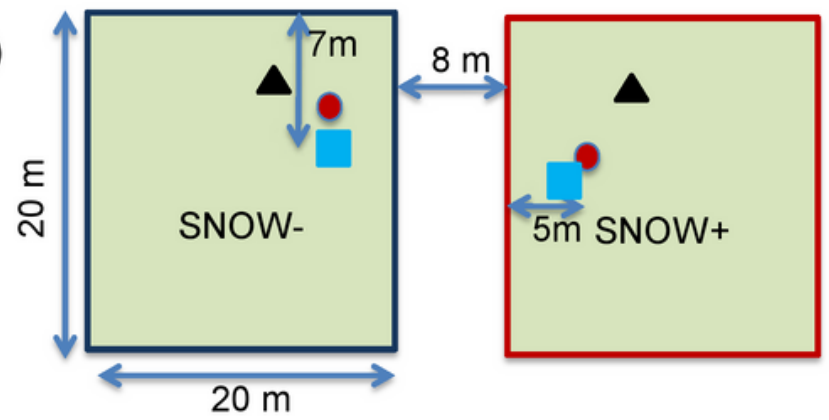

A Time-lapse camera - Soil temperature probes Soil moisture probes

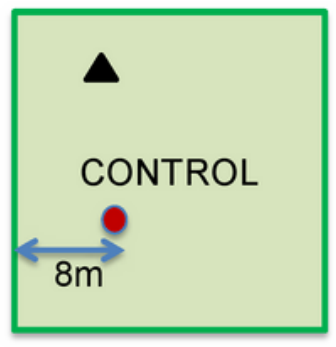

Figure 2. Maps of Eastern Eurasia with locations of Yakutsk, Spasskaya Pad Forest Station, and experimental sites. Maps of (a) Yakutsk (62 $\left.02^{\circ} \mathrm{N}, 129^{\circ} 71^{\prime} \mathrm{E}\right)$, (b) Spasskaya Pad Scientific Forest Station $\left(62^{\circ} 14^{\prime} \mathrm{N}, 129^{\circ} 37^{\prime} \mathrm{E}\right)$, with red square marking experimental sites (white areas are forest, green areas are grassland), and (c) schematic maps of snow manipulation experimental sites.

\section{Figure 2}

See image above for figure legend. 


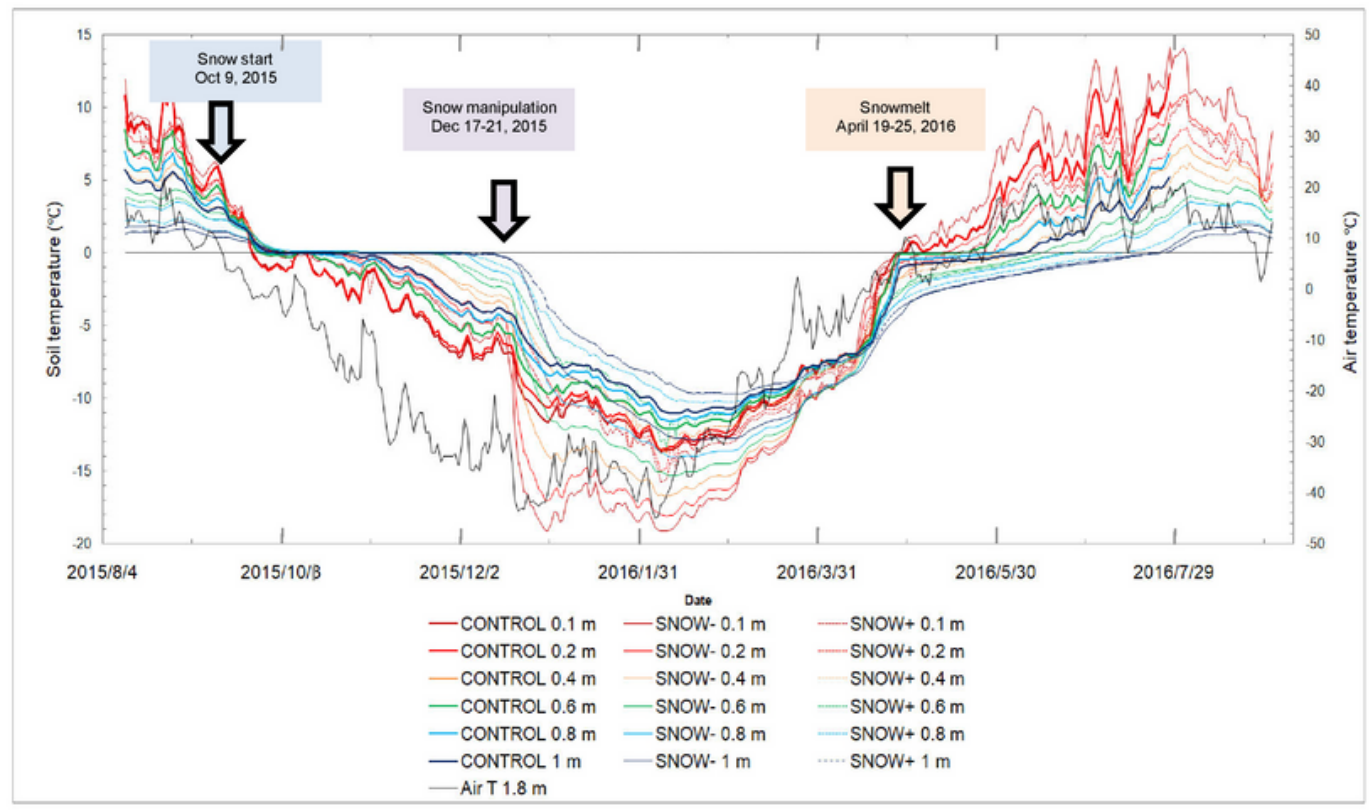

Figure 3. Daily averages of soil temperatures from August 2015 to August 2016. Soil temperature at $0.1,0.2,0.4,0.6,0.8$. and $1 \mathrm{~m}$ depths for SNOW-(thin solid line), SNOW+ (dashed line), and CONTROL (thick solid line) plots, and air temperature at a height of $1.8 \mathrm{~m}$ (solid black line) for the same period are shown.

\section{Figure 3}

See image above for figure legend. 

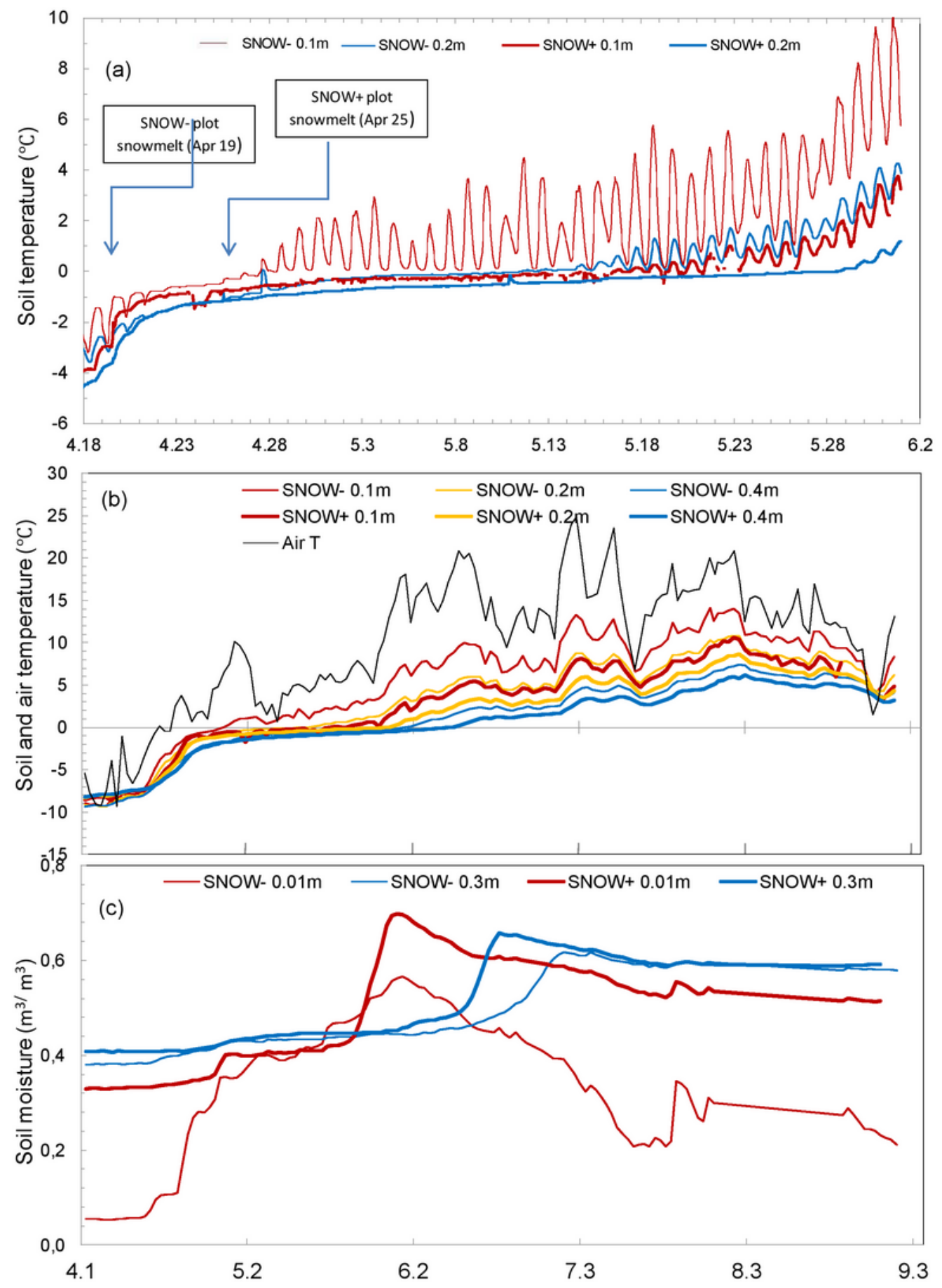

Figure 4. Soil and air temperature, and soil moisture in spring-summer 2016. (a) Hourly soil temperature at $0.1 \mathrm{~m}$ and 0.2 $\mathrm{m}$ depth from April 18 to May 30, 2016; (b) daily average aiband soil temperature at $0.1,0.2$, and $0.4 \mathrm{~m}$ depth, and (c) soil moisture at $0.01 \mathrm{~m}$ and $0.3 \mathrm{~m}$ depth from April to August in 2016 for SNOW- and SNOW+ plots. SNOW- and SNOW+ plots data are represented by thin and thick lines, respectively.

\section{Figure 4}

See image above for figure legend. 


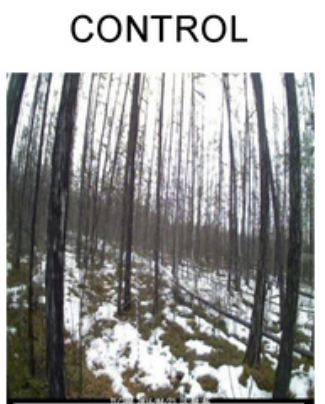

Apr 23
SNOW-

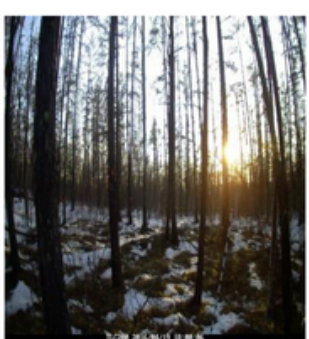

Apr 19
SNOW+

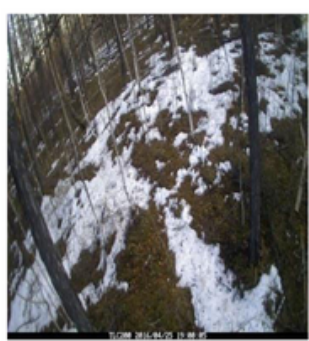

Apr 25

Figure 5. Snowmelt timing observed by time-lapse cameras at CONTROL, SNOW-, and

SNOW+ plots. Date of snowmelt was determined by a criteria of $50 \%$ ground surface appearance.

Snowmelt dates were April 23, April 19, and April 25 for CONTROL, SNOW-, and SNOW+ plots, respectively.

\section{Figure 5}

See image above for figure legend. 


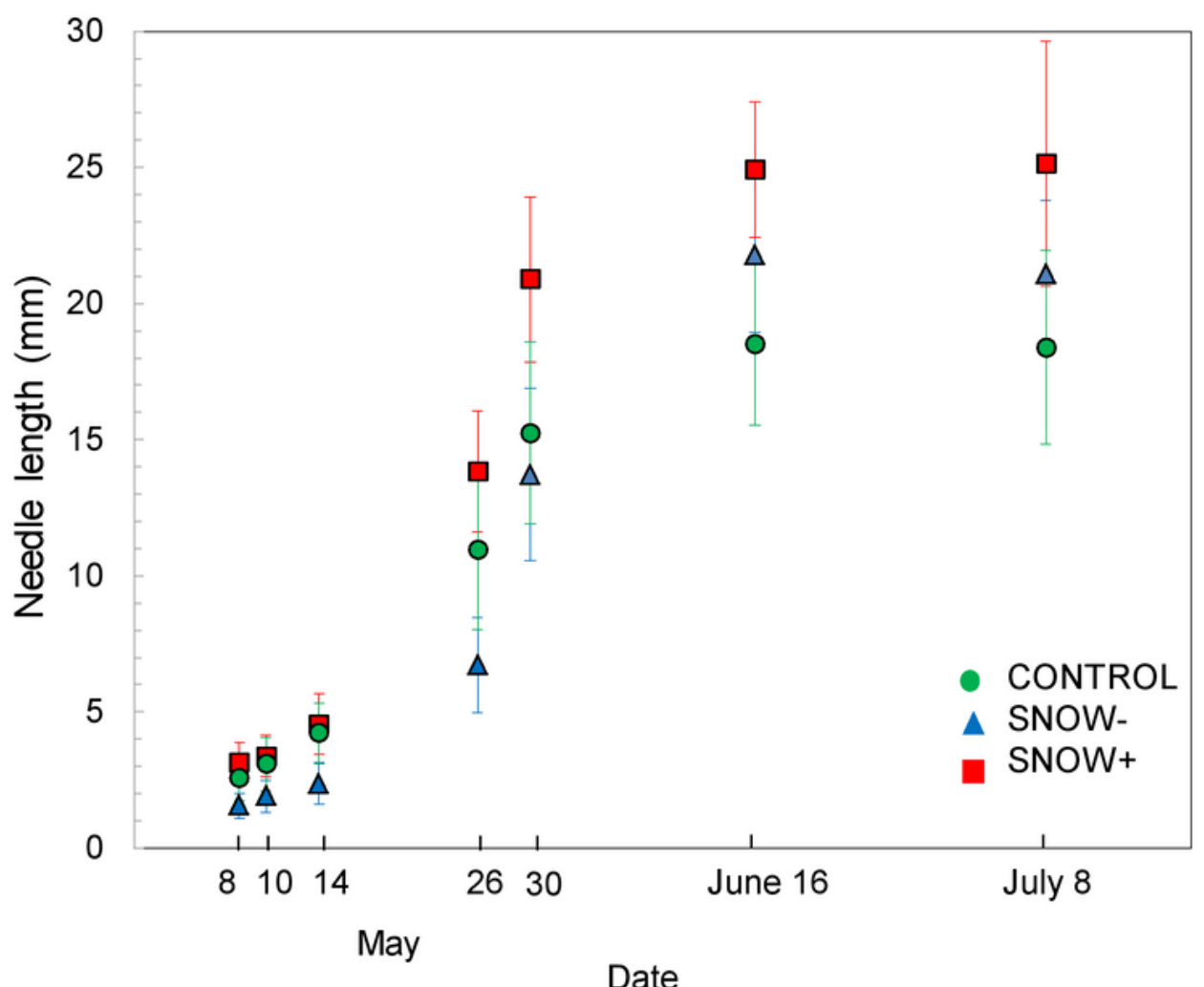

Figure 6. Needle length of small larch trees in spring-summer 2016. Data at CONTROL (green circle) $(\mathrm{n}=55), \mathrm{SNOW}-$ (blue triangle) $(\mathrm{n}=38)$, and $\mathrm{SNOW}+($ red square $)(\mathrm{n}=53)$ plots observed on May 8, 10, 14, 26, and 30, June 16, and July 8, 2016 were shown. Makers and bars are average and standard deviations.

Figure 6

See image above for figure legend. 

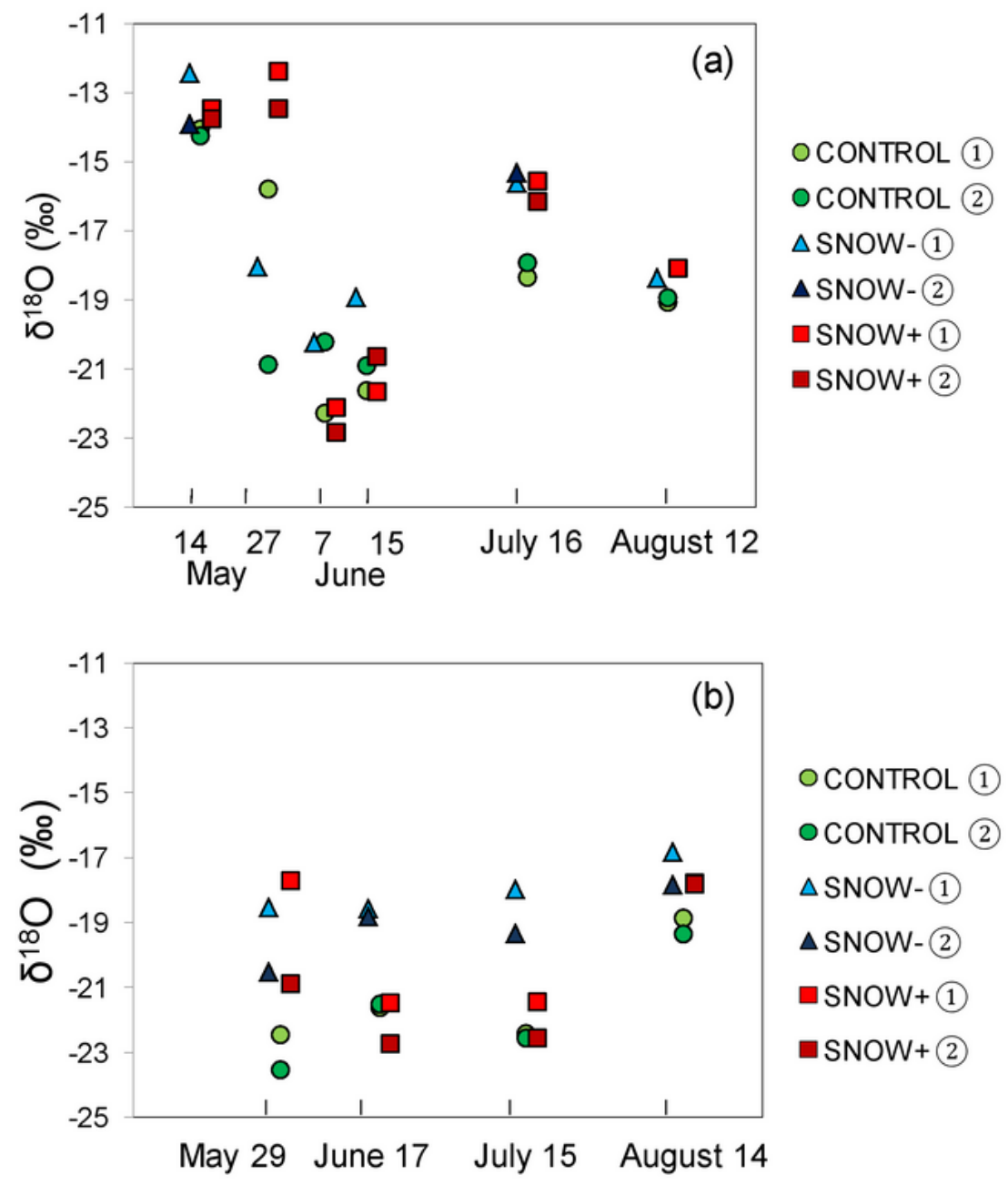

Figure 7. The $\delta^{18} \mathrm{O}$ values of stem water of larch trees. The $\delta^{18} \mathrm{O}$ values observed in (a) 2015 and (b) 2016 at CONTROL (green circle), SNOW- (blue triangle), and $\mathrm{SNOW}+$ (red square) plots are shown.

\section{Figure 7}

See image above for figure legend. 


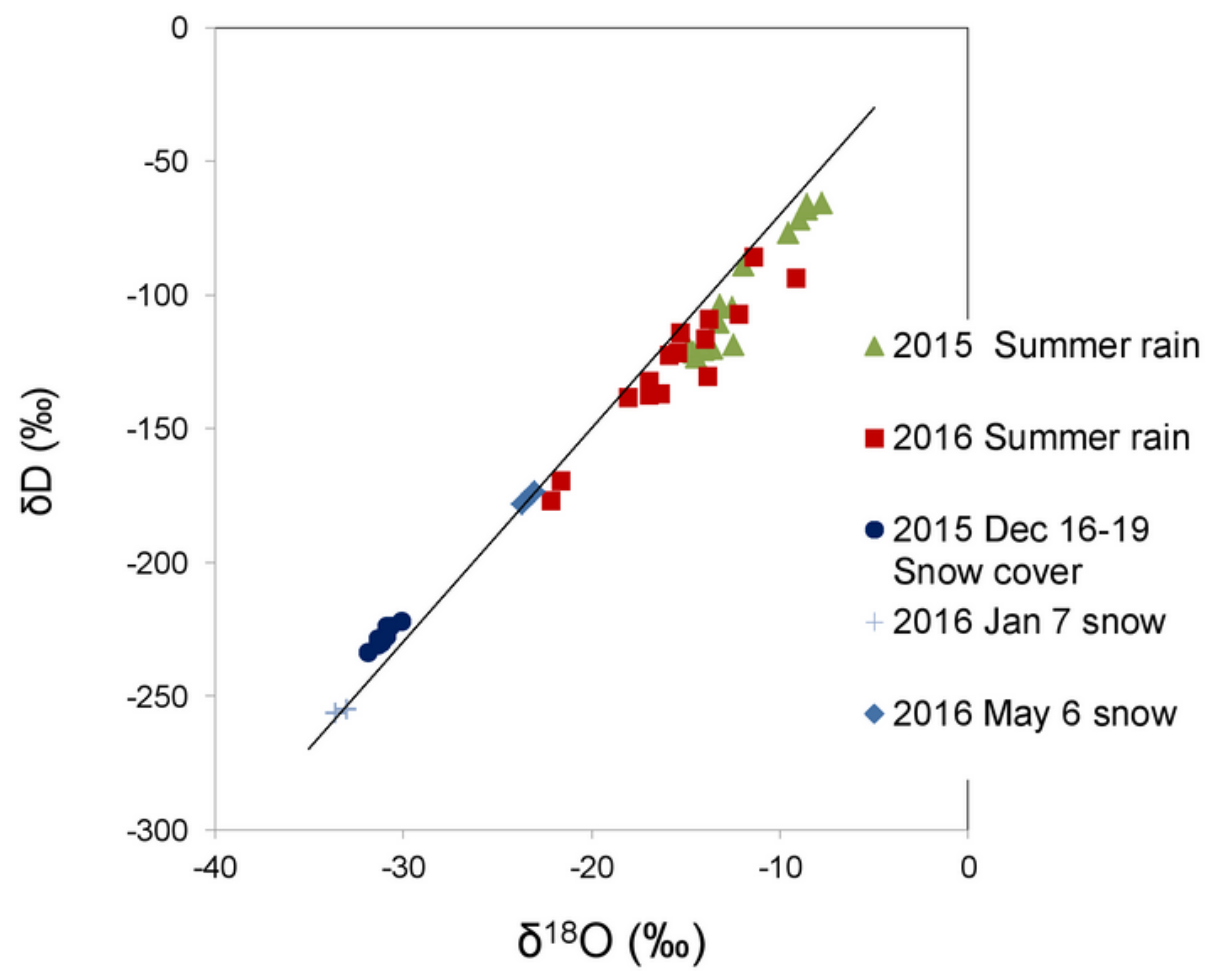

Figure 8 . The $\delta \mathrm{D}-\delta^{18} \mathrm{O}$ plots of precipitation and snow. Summer rainfall in 2015 (green triangle) and 2016 (red square), snow cover on December 16 to 19 in 2015 (blue circle), and fresh snow on January 7 (blue cross) and May 6 (blue diamond) in 2016, and Global Meteoric Water line are also shown.

\section{Figure 8}

See image above for figure legend. 


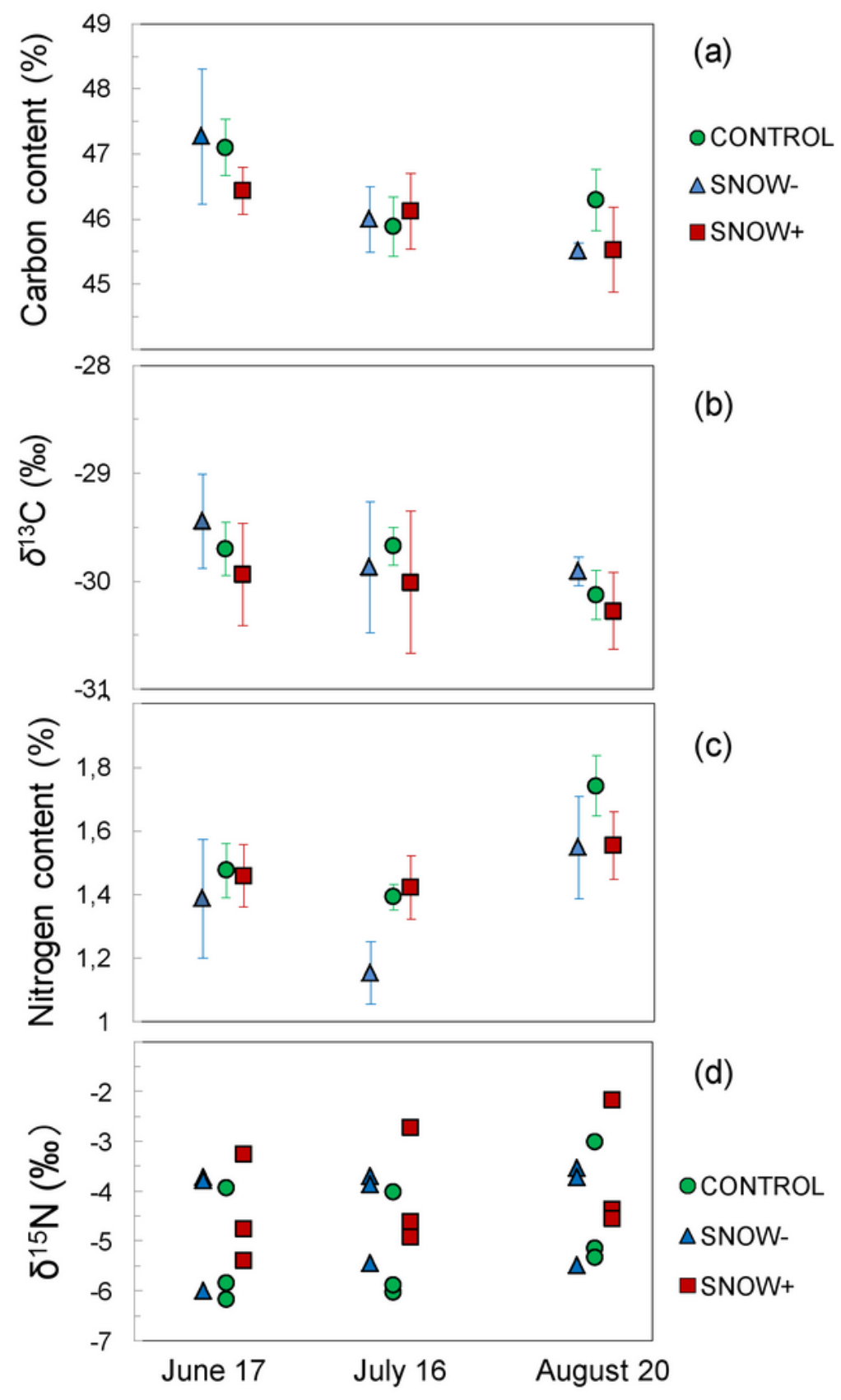

Figure 9. Carbon content, $\delta^{13} \mathrm{C}$, nitrogen content, and $\delta^{15} \mathrm{~N}$ of larch needles in 2016. (a) Carbon content, (b) $\delta^{13} \mathrm{C}$, (c) nitrogen content, and (d) $\delta^{15} \mathrm{~N}$ of larch needles $(\mathrm{n}=3)$ at CONTROL (green circle), SNOW(blue triangle), and SNOW+ (red square) plots in 2016.

\section{Figure 9}

See image above for figure legend. 


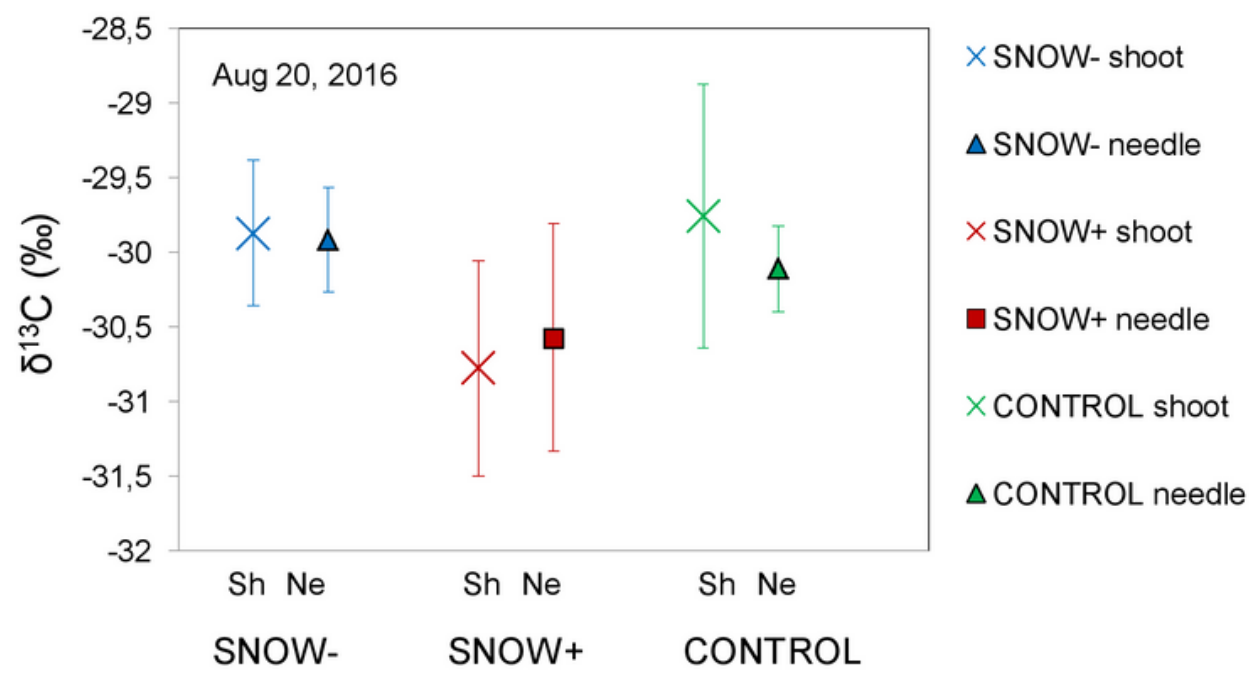

Figure 10. The $\delta^{13} \mathrm{C}$ values of small larch tree shoots and needles. Shoot $(\mathrm{n}=3)$ and shoot needles $(\mathrm{n}=3)$ at $\mathrm{CONTROL}$ (green circle), SNOW- (blue triangle), and $\mathrm{SNOW}+$ (red square) plots sampled on August 20, 2016. Average and standard deviations are shown.

Figure 10

See image above for figure legend. 

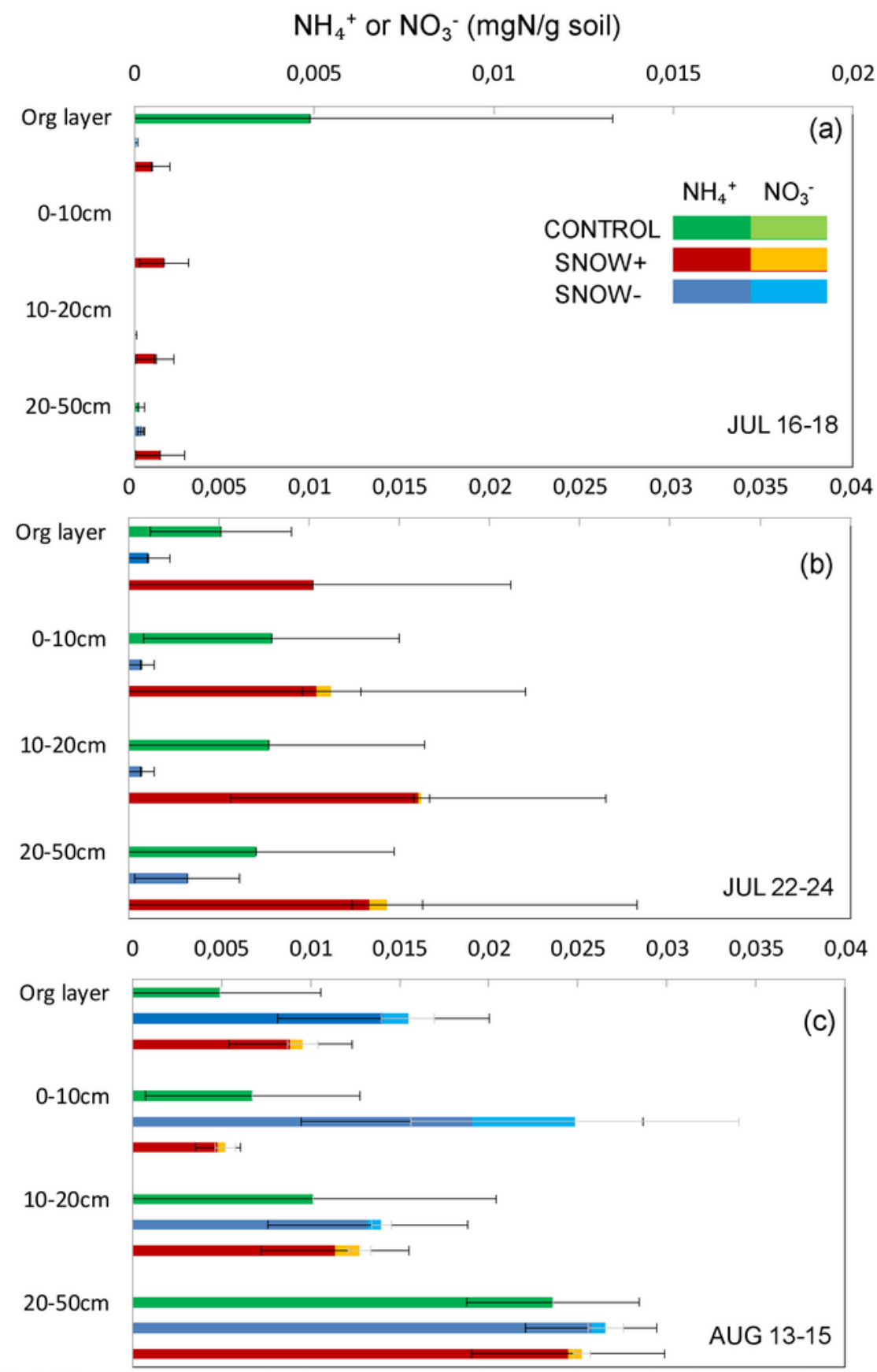

Figure 11. Soil inorganic nitrogen $(n=4)$. Ammonium and nitrate observed in the organic layer and at $0-10$ $\mathrm{cm}, 10-20 \mathrm{~cm}$, and 20-50 cm in (a) mid-July, (b) end of July, and (c) mid-August at CONTROL (green), SNOW+ (red), and SNOW- (blue) plots. Ammonium and nitrate are shown by dark and lighter colors, respectively. No data means that the concentration was below the detection limit.

\section{Figure 11}

See image above for figure legend. 